\title{
Communication
}

\section{HIV-1 Envelope Glycoproteins Proteolytic Cleavage Protects Infected Cells from ADCC Mediated by Plasma from Infected Individuals}

\author{
Jérémie Prévost ${ }^{1,2}$, Halima Medjahed ${ }^{1}$, Dani Vézina $\left.{ }^{1}{ }^{(}\right)$, Hung-Ching Chen ${ }^{3}{ }^{\circledR}$, Beatrice H. Hahn ${ }^{4}(\mathbb{D}$, \\ Amos B. Smith III ${ }^{3}$ and Andrés Finzi ${ }^{1,2, *}$ \\ 1 Centre de Recherche du CHUM, Montreal, QC H2X 0A9, Canada; jeremie.prevost@umontreal.ca (J.P.); \\ halima.medjahed.chum@ssss.gouv.qc.ca (H.M.); dani.vezina@outlook.com (D.V.) \\ 2 Département de Microbiologie, Infectiologie et Immunologie, Université de Montréal, \\ Montreal, QC H2X 0A9, Canada \\ 3 Department of Chemistry, School of Arts and Sciences, University of Pennsylvania, \\ Philadelphia, PA 19104-6323, USA; chenhc@sas.upenn.edu (H.-C.C.); smithab@sas.upenn.edu (A.B.S.III) \\ 4 Departments of Medicine and Microbiology, Perelman School of Medicine, University of Pennsylvania, \\ Philadelphia, PA 19104-6076, USA; bhahn@pennmedicine.upenn.edu \\ * Correspondence: andres.finzi@umontreal.ca
}

check for updates

Citation: Prévost, J.; Medjahed, H.; Vézina, D.; Chen, H.-C.; Hahn, B.H.; Smith, A.B., III; Finzi, A. HIV-1

Envelope Glycoproteins Proteolytic Cleavage Protects Infected Cells from ADCC Mediated by Plasma from Infected Individuals. Viruses 2021, 13, 2236. https://doi.org/10.3390/

v13112236

Academic Editor: Akira Ono

Received: 26 October 2021

Accepted: 4 November 2021

Published: 6 November 2021

Publisher's Note: MDPI stays neutral with regard to jurisdictional claims in published maps and institutional affiliations.

Copyright: (c) 2021 by the authors. Licensee MDPI, Basel, Switzerland. This article is an open access article distributed under the terms and conditions of the Creative Commons Attribution (CC BY) license (https:/ / creativecommons.org/licenses/by/ $4.0 /)$.

\begin{abstract}
The HIV-1 envelope glycoprotein (Env) is synthesized in the endoplasmic reticulum as a trimeric gp160 precursor, which requires proteolytic cleavage by a cellular furin protease to mediate virus-cell fusion. Env is conformationally flexible but controls its transition from the unbound "closed" conformation (State 1) to downstream CD4-bound conformations (States 2/3), which are required for fusion. In particular, HIV-1 has evolved several mechanisms that reduce the premature "opening" of Env which exposes highly conserved epitopes recognized by non-neutralizing antibodies (nnAbs) capable of mediating antibody-dependent cellular cytotoxicity (ADCC). Env cleavage decreases its conformational transitions favoring the adoption of the "closed" conformation. Here we altered the gp160 furin cleavage site to impair Env cleavage and to examine its impact on ADCC responses mediated by plasma from HIV-1-infected individuals. We found that infected primary CD4+ T cells expressing uncleaved, but not wildtype, Env are efficiently recognized by nnAbs and become highly susceptible to ADCC responses mediated by plasma from HIV-1-infected individuals. Thus, HIV-1 limits the exposure of uncleaved Env at the surface of HIV-1-infected cells at least in part to escape ADCC responses.
\end{abstract}

Keywords: HIV-1; Env glycoprotein; furin cleavage site; CD4 mimetics; Temsavir; nnAbs; ADCC; HIV+ plasma

\section{Introduction}

The human immunodeficiency virus type 1 (HIV-1) envelope glycoprotein (Env) is a class I viral membrane fusion protein which mediates viral entry using the CD4 cellular receptor. The envelope gp160 precursor is synthesized in the endoplasmic reticulum (ER) and oligomerizes as a trimer [1,2]. Subsequently, the trimeric Env traffics through the transGolgi network (TGN) to reach the plasma membrane and to be incorporated into nascent HIV-1 virions [3-5]. During its transit through the secretory pathway, Env undergoes important post-translational modifications, including N-linked and O-linked glycosylation as well as proteolytic cleavage [6-10]. The addition of high-mannose oligosaccharides takes place in the ER and these glycans are further processed to acquire complex modifications in the TGN [11]. Concomitantly, proprotein convertases present in the TGN, including furin and furin-like proteases, catalyze the cleavage of the immature gp160 polyprotein [12-15] into two functional non-covalently linked subunits: the exterior gp120 subunit, which is responsible for viral attachment and the transmembrane gp41 subunit, which mediates 
membrane fusion. The human furin protein is part of the subtilisin-like serine endoprotease family and recognizes polybasic motifs, having Arg-X-Lys/Arg-Arg (RXK/RR) as a consensus cleavage site [16]. HIV-1 Env possesses a highly conserved furin cleavage site at the gp120-gp41 junction $\left({ }^{508} \mathrm{REKR}^{511}\right)$ which is adjacent to the hydrophobic fusion peptide at the gp41 N-terminus, with furin cleavage being essential for viral infectivity $[6,8,17,18]$. A putative secondary furin cleavage site $\left({ }^{500} \mathrm{KAKR}^{503}\right)$, located a few residues upstream of the primary cleavage site, has been described but its function remains unclear $[17,19]$.

The functional mature Env trimer is known to sample different conformations ranging from the pre-fusion "closed" metastable conformation (State 1) to the CD4-bound "open" conformation (State 3), transitioning through an intermediate asymmetric conformation (State 2) $[20,21]$. Env glycoproteins from primary isolates preferentially adopt the State 1 conformation, which is preferentially recognized by broadly neutralizing antibodies (bNAbs) [20,22-24] and can be triggered into downstream conformations by CD4 binding, which exposes highly conserved epitopes targeted by non-neutralizing antibodies (nnAbs) $[20,25,26]$. These nnAbs are rapidly elicited upon infection and vaccination [27-32] and mediate potent Fc-effector functions, including antibody-dependent cellular cytotoxicity (ADCC) [26,33-38]. The binding of Env to CD4 on the surface of HIV-1-infected cells stabilizes Env in State 2A, which is highly susceptible to nnAbs-mediated ADCC [26,39,40]. However, HIV-1 has evolved to prevent the premature adoption of the CD4-bound conformation by downregulating and degrading pre-existing and newly-synthesized CD4 through its accessory proteins Nef and Vpu [26,35,41,42]. Small CD4 mimetic compounds (CD4mc) are being developed to "open up" Env, with the goal of harnessing the potential of nnAbs responses for prevention [31,32,38,43-46] and eradication [36,40,47-53] strategies. Another class of Env antagonists known as conformational blockers, which includes the FDA-approved drug Temsavir, prevents Env transitions to downstream conformations by stabilizing Env State 1 [20,22,54,55].

Besides Env-CD4 interaction, there are also structural features of HIV-1 Env that can modulate the sensitivity of HIV-1 to ADCC responses mediated by nnAbs present in plasma from infected individuals. Natural polymorphisms in the Phe43 cavity (notably in CRF01_AE strains) and mutations of conserved residues in the trimer association domain have been shown to modulate Env conformation [25,56-59] and as a result, the susceptibility of cells infected with these viruses to ADCC responses [51,60,61]. Similarly, proteolytic cleavage has been reported to stabilize a "closed" Env conformation [62-65], since mutations in the furin cleavage site resulted in the spontaneous sampling of downstream conformations, including Env State 2A [40,55,63]. Here we evaluate the impact of altering the Env furin cleavage site on the susceptibility of infected primary CD4+ T cells to ADCC responses mediated by HIV+ plasma.

\section{Materials and Methods}

\subsection{Ethics Statement}

Written informed consent was obtained from all study participants (the Montreal Primary HIV Infection Cohort $[66,67]$ and the Canadian Cohort of HIV Infected Slow Progressors [68-70]), and research adhered to the ethical guidelines of CRCHUM and was reviewed and approved by the CRCHUM institutional review board (ethics committee, approval number CE 16.164-CA). The research adhered to the standards indicated by the Declaration of Helsinki. All participants were adults and provided informed written consent prior to enrolment in accordance with Institutional Review Board approval.

\subsection{Cell Lines and Primary Cells}

293T human embryonic kidney cells (obtained from ATCC) and TZM-bl cells (NIH AIDS Reagent Program) were maintained at $37^{\circ} \mathrm{C}$ under $5 \% \mathrm{CO}_{2}$ in Dulbecco's Modified Eagle Medium (DMEM) (Wisent, St. Bruno, QC, Canada), supplemented with 5\% fetal bovine serum (FBS) (VWR, Radnor, PA, USA) and $100 \mathrm{U} / \mathrm{mL}$ penicillin/streptomycin (Wisent). 293T cells were derived from 293 cells, into which the simian virus 40 T-antigen 
was inserted. TZM-bl were derived from HeLa cells and were engineered to stably express high levels of human CD4 and CCR5 and to contain the firefly luciferase reporter gene under the control of the HIV-1 promoter [71]. Primary human PBMCs and CD4+ T cells were isolated, activated, and cultured as previously described [26]. Briefly, PBMCs were obtained by leukapheresis from six HIV-negative individuals (all males), and primary CD4+ $\mathrm{T}$ lymphocytes were purified from resting PBMCs by negative selection using immunomagnetic beads per the manufacturer's instructions (StemCell Technologies, Vancouver, $\mathrm{BC}$, Canada) and were activated with phytohemagglutinin-L $(10 \mu \mathrm{g} / \mathrm{mL})$ for $48 \mathrm{~h}$ and then maintained in RPMI-1640 (Thermo Fisher Scientific, Waltham, MA, USA) complete medium supplemented with rIL-2 $(100 \mathrm{U} / \mathrm{mL})$.

\subsection{Antibodies and Sera}

The following Abs were used to assess Env conformation at the cell surface: conformationindependent anti-gp120 outer-domain 2G12 (NIH AIDS Reagent Program), broadly- neutralizing antibodies anti-CD4 binding site VRC03 (NIH AIDS Reagent Program), anti-V2 apex PG9 (Polymun Scientific, Klosterneuburg, Austria), anti-V3 glycan PGT126, antigp41-gp120 interface PGT151 (IAVI), anti-V3 glycan 10-1074 (kindly provided by Michel Nussenzweig) and anti-fusion peptide VRC34 (kindly provided by John Mascola) as well as non-neutralizing antibodies anti-gp41 C-C loop F240, anti-V3 crown 19b, anti-coreceptor binding site 17b, anti-cluster A A32 and C11 (NIH AIDS Reagent Program). The HIV-IG polyclonal antibody consists of anti-HIV immunoglobulins purified from a pool of plasma from HIV+ asymptomatic donors (NIH AIDS Reagent Program). Goat anti-human and anti-mouse antibodies pre-coupled to Alexa Fluor 647 (Invitrogen, Rockford, IL, USA) were used as secondary antibodies in flow cytometry experiments. Plasma from HIV-infected individuals was collected, heat-inactivated and conserved at $-80^{\circ} \mathrm{C}$ until use. In most experiments, the 2G12 monoclonal $\mathrm{Ab}(\mathrm{mAb})$ was used to normalize Env expression because of its conformation independence. Both viruses used in the study (CH058 and $\mathrm{CH} 077$ ) are well recognized by 2G12 despite polymorphism found at position 295 in CH077 Env.

\subsection{Small Molecules}

The small-molecule CD4-mimetic compound BNM-III-170 was synthesized as described previously [72]. The HIV-1 attachment inhibitor Temsavir (BMS-626529) was purchased from APExBIO (Houston, TX, USA). The compounds were dissolved in dimethyl sulfoxide (DMSO) at a stock concentration of $10 \mathrm{mM}$ and diluted to $50 \mu \mathrm{M}$ in phosphatebuffered saline (PBS) for cell-surface staining and virus capture assay or in RPMI-1640 complete medium for ADCC assays.

\subsection{Plasmids and Proviral Constructs}

The vesicular stomatitis virus G (VSV-G)-encoding plasmid was previously described [73]. Transmitted/Founder (T/F) infectious molecular clones (IMCs) of patients $\mathrm{CH} 058$ and CH077 were previously reported [74-77]. To generate IMCs encoding for cleavage-deficient Env, two mutations (R508S/R511S) were introduced in the furin cleavage site $\left({ }^{508}\right.$ REKR $\left.^{511}\right)$ using the QuikChange II XL site-directed mutagenesis protocol (Agilent Technologies, Santa Clara, CA). The presence of the desired mutations was determined by automated DNA sequencing.

\subsection{Radioactive Labeling and Immunoprecipitation of Envelope Glycoproteins}

293T cells $\left(3 \times 10^{5}\right)$ were transfected by the calcium phosphate method with the different IMCs. One day after transfection, cells were metabolically labeled for $16 \mathrm{~h}$ with $100 \mu \mathrm{Ci} / \mathrm{mL}$ of $\left[{ }^{35} \mathrm{~S}\right]$ methionine-cysteine $\left(\left[{ }^{35} \mathrm{~S}\right]\right.$ Protein Labeling Mix; PerkinElmer, Waltham, MA, USA) in DMEM lacking methionine and cysteine and supplemented with 5\% dialyzed fetal bovine serum. Cells were subsequently lysed in RIPA buffer $(140 \mathrm{mM} \mathrm{NaCl}, 8 \mathrm{mM}$ $\mathrm{Na}_{2} \mathrm{HPO}_{4}, 2 \mathrm{mM} \mathrm{NaH} \mathrm{PO}_{4}, 1 \% \mathrm{NP} 40,0.05 \%$ sodium dodecyl sulfate (SDS), $1.2 \mathrm{mM}$ sodium deoxycholate). Precipitation of radiolabeled envelope glycoproteins from the whole-cell 
lysates or found in the supernatant was performed with a pool of sera from HIV-1-infected individuals in the presence of $50 \mu \mathrm{L}$ of $10 \%$ Protein A-Sepharose (Cytiva, Marlborough, MA) at $4{ }^{\circ} \mathrm{C}$. The precipitated proteins were loaded onto SDS-PAGE gels and analyzed by autoradiography and densitometry to calculate their processing indexes. The processing index is a measure of the conversion of the mutant gp160 Env precursor to mature gp120, relative to wild-type Env trimers. The processing index is calculated with the following formula: processing index $=([$ total gp120]mutant $\times$ [gp160]WT $) /([g p 160]$ mutant $\times[$ total gp120]WT).

\subsection{Viral Production and Infections}

VSV-G-pseudotyped HIV-1 viruses were produced and concentrated as previously described [60]. Viruses were then used to infect activated primary CD4+ T cells from healthy HIV-1 negative donors by spin infection at $800 \times g$ for $1 \mathrm{~h}$ in 96 -well plates at $25{ }^{\circ} \mathrm{C}$. Viral preparations were titrated directly on primary CD4+ T cells to achieve similar levels of infection among the different IMCs tested (around 10\% of p24+ cells). To assess viral infectivity, TZM-bl reporter cells were seeded at a density of $2 \times 10^{4}$ cells/well in 96-well luminometer-compatible tissue culture plates (PerkinElmer) $24 \mathrm{~h}$ before infection. Normalized amounts of viruses (according to reverse transcriptase activity [78]) in a final volume of $100 \mu \mathrm{L}$ were then added to the target cells and incubated for $48 \mathrm{~h}$ at $37^{\circ} \mathrm{C}$. The medium was then removed from each well, and the cells were lysed by the addition of $30 \mu \mathrm{L}$ of passive lysis buffer (Promega, Madison, WI, USA) and one freeze-thaw cycle. An LB 941 TriStar luminometer (Berthold Technologies, Bad Wildbad, Germany) was used to measure the luciferase activity of each well after the addition of $100 \mu \mathrm{L}$ of luciferin buffer (15 mM MgSO $4,15 \mathrm{mM} \mathrm{KH}_{2} \mathrm{PO}_{4}$ [pH 7.8], $1 \mathrm{mM}$ ATP, and $1 \mathrm{mM} 170$ dithiothreitol) and $50 \mu \mathrm{L}$ of $1 \mathrm{mM}$ D-luciferin potassium salt (Prolume, Pinetop, AZ, USA).

\subsection{Virus Capture Assay}

The HIV-1 virus capture assay was previously reported [79]. Pseudoviral particles were produced by transfecting $2 \times 10^{6} 293 \mathrm{~T}$ cells with pNL4.3 R-E- Luc (NIH AIDS Reagent Program) $(3.5 \mu \mathrm{g}), \mathrm{HIV}-1_{\mathrm{CH} 058}(3.5 \mu \mathrm{g})$, and VSV-G $(1 \mu \mathrm{g})$ using the standard calcium phosphate method. Forty-eight hours later, virus-containing supernatant was collected, and cell debris were removed by centrifugation (1500 rpm for $10 \mathrm{~min}$ ). Anti-Env antibodies was immobilized on white MaxiSorp ELISA plates (Thermo Fisher Scientific) at a concentration of $5 \mu \mathrm{g} / \mathrm{mL}$ in $100 \mu \mathrm{L}$ of PBS overnight at $4{ }^{\circ} \mathrm{C}$. Unbound antibodies were removed by washing twice the plates twice with PBS. Plates were subsequently blocked with $3 \%$ bovine serum albumin (BSA) in PBS for $1 \mathrm{~h}$ at room temperature. After washing plates twice with PBS, $200 \mu \mathrm{L}$ of virus-containing supernatants were added to the wells. After 4 to $6 \mathrm{~h}$ incubation, virions were removed, and the wells were washed three times with PBS. Virus capture by any given antibody was visualized by adding $1 \times 10^{4} 293 \mathrm{~T}$ cells per well in complete DMEM. To measure recombinant virus infectivity, $1 \times 10^{4} 293 \mathrm{~T}$ cells were directly mixed with $100 \mu \mathrm{L}$ of virus-containing supernatants per well. Forty-eight hours post-infection, cells were lysed by the addition of $30 \mu \mathrm{L}$ of passive lysis buffer (Promega) and one freeze-thaw cycle. An LB 941 TriStar luminometer (Berthold Technologies) was used to measure the luciferase activity of each well after the addition of $100 \mu \mathrm{L}$ of luciferin buffer (15 mM MgSO, $15 \mathrm{mM} \mathrm{KH}_{2} \mathrm{PO}_{4}$ [pH 7.8], $1 \mathrm{mM}$ ATP, and $1 \mathrm{mM}$ dithiothreitol) and $50 \mu \mathrm{L}$ of $1 \mathrm{mM}$ D-luciferin potassium salt (Prolume).

\subsection{Flow Cytometry Analysis of Cell-Surface and Intracellular Staining}

Cell-surface staining of HIV-1-transfected and HIV-1-infected cells was executed as previously described [35,61]. For transfected cells, we used the standard calcium phosphate method to transfect $7 \mu \mathrm{g}$ of each IMC into $2 \times 10^{6} 293 \mathrm{~T}$ cells. Binding of cell-surface HIV-1 Env by anti-Env mAbs $(5 \mu \mathrm{g} / \mathrm{mL})$ or HIV+ plasma (1:1000 dilution) was performed at $48 \mathrm{~h}$ post-transfection. Similarly, cell-surface staining of infected cells was performed at $48 \mathrm{~h}$ post-infection. After cell-surface staining, transfected cells and infected cells were 
permeabilized using the Cytofix/Cytoperm Fixation/Permeabilization Kit (BD Biosciences, Mississauga, ON, Canada) and stained intracellularly using PE-conjugated mouse antip24 mAb (clone KC57; Beckman Coulter, Brea, CA, USA; 1:100 dilution). The percentage of transfected or infected cells (p24+) was determined by gating on the living cell population according to a viability dye staining (Aqua Vivid, Thermo Fisher Scientific). Samples were acquired on an LSRII cytometer (BD Biosciences), and data analysis was performed using FlowJo v10.5.3 (Tree Star, Ashland, OR, USA).

\subsection{FACS-Based ADCC Assay}

Measurement of ADCC using the FACS-based assay was performed at $48 \mathrm{~h}$ postinfection as previously described [26,36]. Briefly, HIV-1-infected primary CD4+ T cells were stained with AquaVivid viability dye and cell proliferation dye eFluor670 (Thermo Fisher Scientific) and used as target cells. Autologous PBMC effectors cells, stained with the cell proliferation dye eFluor450 (Thermo Fisher Scientific), were added at an effector: target ratio of 10:1 in 96-well V-bottom plates (Corning, Glendale, AZ, USA). A 1:1000 final dilution of HIV+ plasma was added to appropriate wells and cells were incubated for $5 \mathrm{~min}$ at room temperature. The plates were subsequently centrifuged for $1 \mathrm{~min}$ at $300 \times g$ and incubated at $37{ }^{\circ} \mathrm{C}, 5 \% \mathrm{CO}_{2}$ for $5 \mathrm{~h}$ before being fixed in a $2 \%$ PBS-formaldehyde solution. Samples were acquired on an LSRII cytometer (BD Biosciences) and data analysis was performed using FlowJo v10.5.3 (Tree Star). The percentage of ADCC was calculated with the following formula: (\% of p24+ cells in Targets plus Effectors) - (\% of p24+ cells in Targets plus Effectors plus sera)/(\% of p24+ cells in Targets) by gating on infected lived target cells.

\subsection{Statistical Analysis}

Statistics were analyzed using GraphPad Prism version 9.1.0 (GraphPad, San Diego, CA, USA). Every data set was tested for statistical normality and this information was used to apply the appropriate (parametric or nonparametric) statistical test. $p$ values $<0.05$ were considered significant; significance values are indicated as ${ }^{*} p<0.05,{ }^{* *} p<0.01$, *** $p<0.001,{ }^{* * * *} p<0.0001$.

\section{Results}

\subsection{Conformation of HIV-1 Uncleaved Env at the Surface of Infected Cells and Viral Particles}

To study the role of the furin cleavage site on Env conformation, we performed mutagenesis on the infectious molecular clones (IMCs) of clade B transmitted/founder (T/F) viruses $\mathrm{CH} 058$ and $\mathrm{CH} 077$. Envs from both viruses were previously shown to preferentially sample the "closed" State 1 conformation [61]. We introduced substitutions in the primary cleavage site at position 508 and 511 (Figure 1A), to replace the highly conserved arginine residues with serine residues (R508S/R511S; referred as Cl- mutant), a double mutant known to efficiently abrogate furin-dependant Env processing [64,80-82]. We used protein radioactive labelling of $293 \mathrm{~T}$ cells transfected with the different IMC constructs followed by Env immunoprecipitation to confirm the effect of the mutations on Env cleavage (Figure 1B-E). As expected, Env glycoproteins expressed from the wild-type (WT) construct were efficiently cleaved while their cleavage-deficient $(\mathrm{Cl}-)$ counterpart yielded little to no detectable gp120 in the 293T whole-cell lysates (Figure 1B,D). Although we observed some soluble gp120 in the supernatant of CH058-transfected cells, this was likely due to the presence of a second upstream cleavage site, which matched the furin consensus sequence (RAKR). The supernatant of CH077-transfected cells did not contain gp120 consistent with an altered upstream cleavage site (KAKR) (Figure 1A). Of note, two bands of gp160 with distinct molecular weights were observed in cells transfected with $\mathrm{Cl}$ - variants, a phenotype previously observed that was linked to a difference in Env trafficking and localization [83-85]. 
A

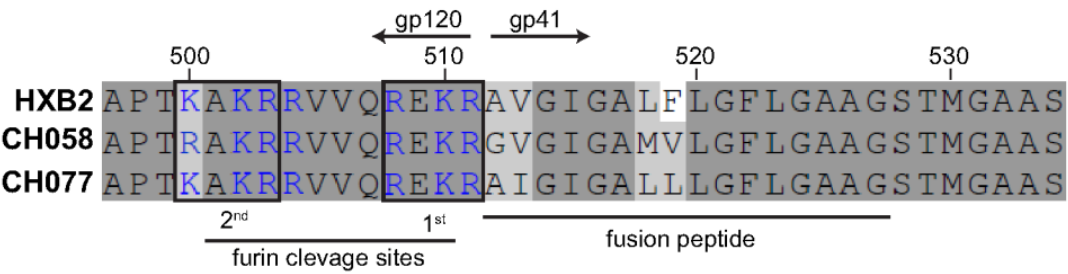

B

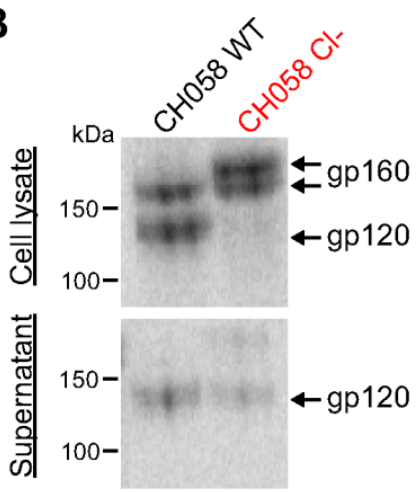

C

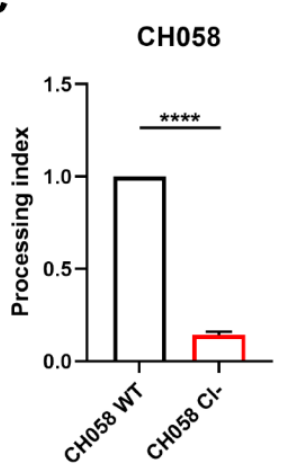

D

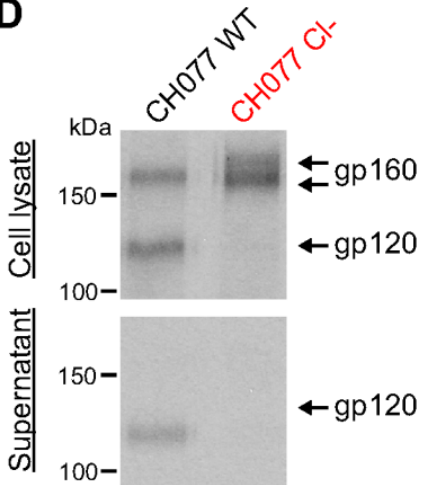

E

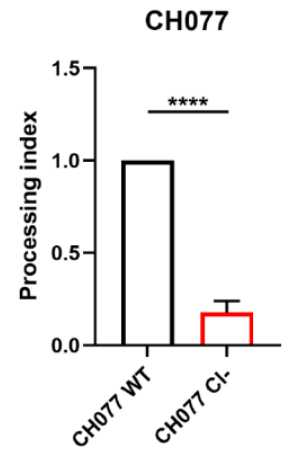

F

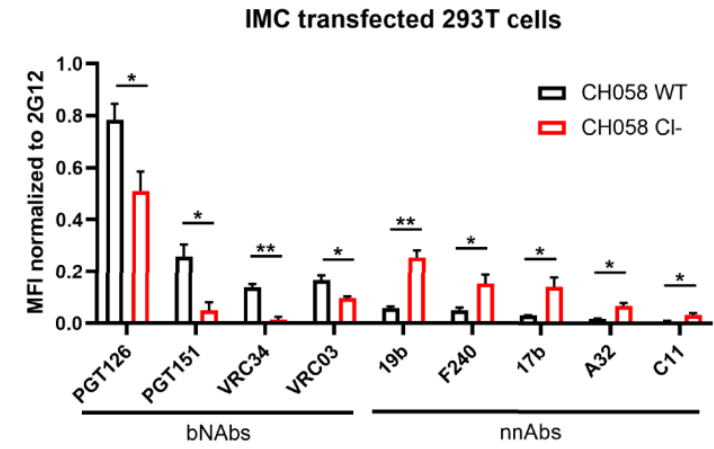

H

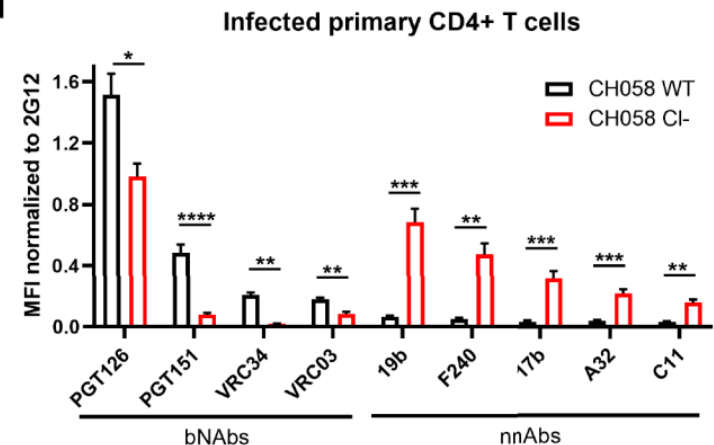

G

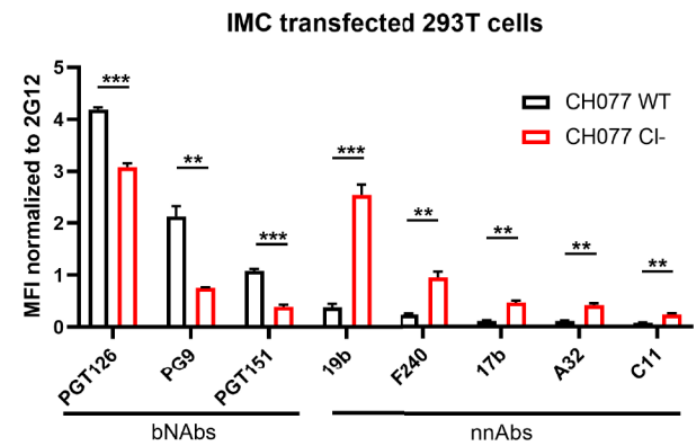

I

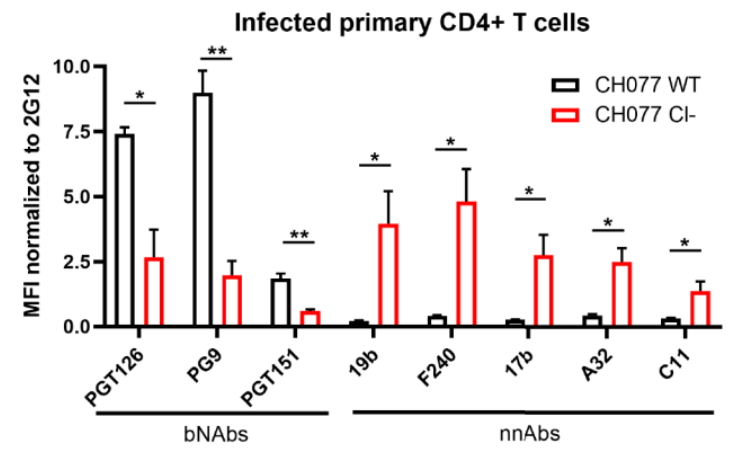

Figure 1. Proteolytic cleavage stabilizes Env in its "closed" conformation. (A) Sequence alignment of the HIV-1 Env furin cleavage site region from primary viruses CH058 (GenBank accession number JN944940) and CH077 (GenBank accession number JN944941) with the HXB2 reference strain (GenBank accession number K03455). Putative furin cleavage sequences are highlighted by black boxes. Positively charged residues (arginine and lysine) are shown in blue. Residue numbering is based on the HXB2 strain. Identical residues are shaded in dark gray, and conserved residues are shaded in light gray. (B-E) 293T cells were transfected with primary IMCs (B,C) CH058, (D,E) CH077 WT or their cleavage-deficient (Cl-) variants and metabolically labeled with $\left[{ }^{35} \mathrm{~S}\right]$-methionine and $\left[{ }^{35} \mathrm{~S}\right]$-cysteine. (B,D) Cell lysates and supernatants were immunoprecipitated with plasma from HIV-1-infected individuals. The precipitated proteins were loaded onto SDS-PAGE 
gels and analyzed by autoradiography and densitometry to calculate their processing indexes. The processing index is a measure of the conversion of the mutant gp160 Env precursor to mature gp120, relative to the wild-type Env trimer. (C,E) Shown is the average of processing indexes calculated in 3 independent experiments. (F-I) Cell-surface staining of (F,G) IMC transfected 293T cells $(\mathbf{H}, \mathbf{I})$ or primary CD4+ T cells infected with IMCs (F,H) CH058 and (G,I) CH077 WT or their cleavage-deficient (Cl-) variants using a panel of anti-Env bNAbs (PGT126, PG9, PGT151, VRC34, VRC03) and nnAbs (19b, F240, 17b, A32, C11). Shown are the mean fluorescence intensities (MFI) using the different antibodies normalized to the signal obtained with the conformation-independent $2 \mathrm{G} 12 \mathrm{mAb}$. MFI values were measured on the transfected or infected (p24+) population for staining obtained in at least 3 independent experiments. Error bars indicate the mean \pm SEM. Statistical significance was tested using an unpaired $t$-test $\left({ }^{*} p<0.05,{ }^{* *} p<0.01,{ }^{* * *} p<0.001\right.$, $* * * * p<0.0001)$.

Subsequently, we evaluated the ability of a panel of bNAbs and nnAbs to recognize the cleaved (WT) and uncleaved (Cl-) Env at the surface of 293T cells. We selected these cells since they do not express CD4 and it has been well documented that the presence of CD4 affects Env conformation $[26,35,86]$. Cells were transfected with the different IMC constructs and virus-expressing cells were identified using Gag p24 staining (Figure 1F,G). Cell-surface Env expression was normalized using the conformation-independent 2G12 antibody. Cells expressing WT Env were preferentially recognized by the bNAbs preferring the State 1 conformation (PGT126, VRC03, PG9) and recognizing the fusion peptide (PGT151, VRC34) compared to those expressing the respective cleavage site mutants (Figure $1 \mathrm{~F}, \mathrm{G}$ ). Conversely, the binding of nnAbs targeting the downstream conformations States 2/3 (19b, F240, 17b) and State 2A (A32, C11) was significantly enhanced on cells expressing uncleaved Env (Figure 1F,G). To confirm this phenotype in a physiologically more relevant culture system, we infected activated primary CD4+ T cells with the different primary IMCs. Of note, all viruses were pseudotyped with the VSV G glycoprotein to normalize the level of infection and to compensate for the inability of uncleaved Env to mediate viral fusion. Consistent with the 293T results, productively-infected cells (p24+ CD4 $4_{\text {low }}$ ) were more efficiently recognized by bNAbs when expressing cleaved Env, and by nnAbs when expressing uncleaved Env (Figure 1H,I). Overall, these results support and extend previous observations indicating that furin cleavage favors the adoption of the native "closed" conformation at the cell surface $[40,65,84]$.

We next investigated the effect of furin cleavage on Env conformation at the surface of viral particles, since the viral membrane is known to be enriched in cholesterol, a lipid known to stabilize Env State 1 conformation by interacting with the gp41 membraneproximal external region (MPER) [87-89]. Since virions expressing the Env $\mathrm{Cl}$-variants were unable to infect even highly permissive cells, we used a recently developed virus capture assay [79] (Figure 2A). Specifically, we generated luciferase reporter pseudovirions that contained both HIV-1 Env and VSV G glycoproteins, thus allowing captured virions to infect $293 \mathrm{~T}$ cells in an Env-independent manner (i.e., 293T infection is driven by the incorporated VSV G glycoprotein, Figure 2B). Virions harboring WT Env were captured more efficiently by bNAbs, while virions harboring uncleaved Env were primarily bound by nnAbs (Figure 2C). The recognition of pseudovirions was also assessed using purified anti-HIV-1 immunoglobulins from HIV+ asymptomatic donors (HIV-IG) [90]. Since the vast majority of naturally-elicited antibodies targets Env in its "open" conformation [26,27,34], HIV-IG polyclonal antibodies captured viral particles displaying immature Env in a larger proportion (Figure 2D). HIV-IG specific capture of uncleaved or cleaved Env could be further increased using the small molecule CD4mc BNM-III-170, which stabilizes the CD4-bound conformation (Figure 2D). Alternatively, treatment with the conformational blocker Temsavir decreased the capacity of HIV-IG to capture viral particles bearing $\mathrm{Cl}-$ Envs (Figure 2D), in agreement with its capacity to stabilize the "closed" conformation $[20,22,55]$. These results indicate that uncleaved Env can be forced into "open" or "closed" conformations using small molecule Env antagonists. 
A

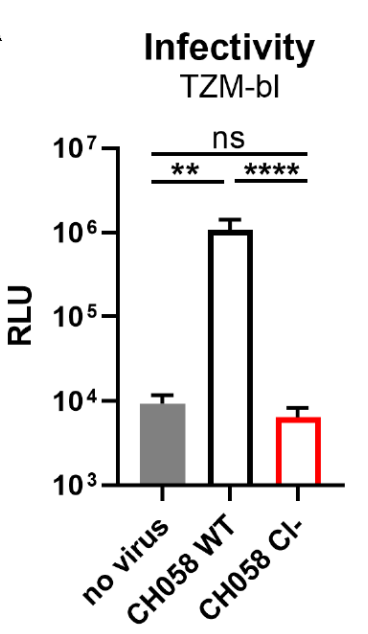

B

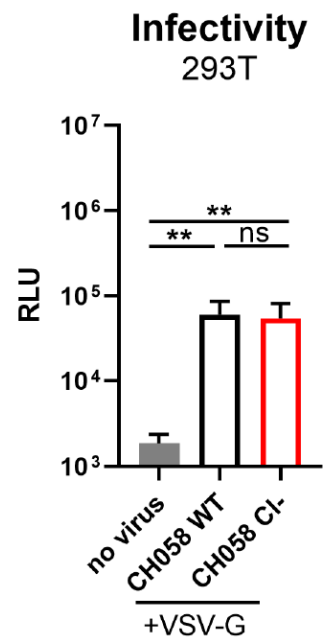

C

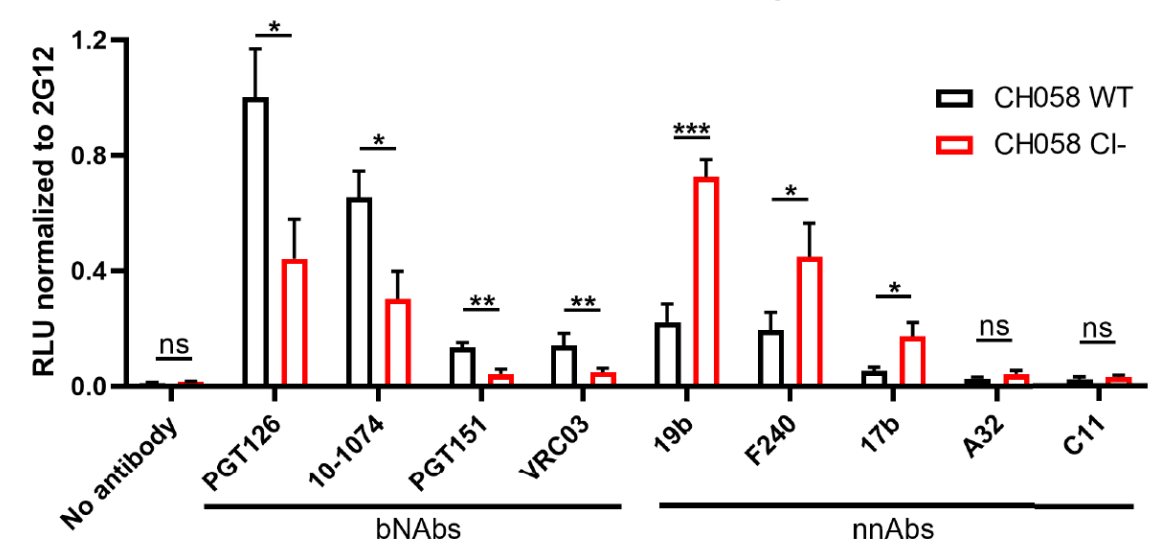

D

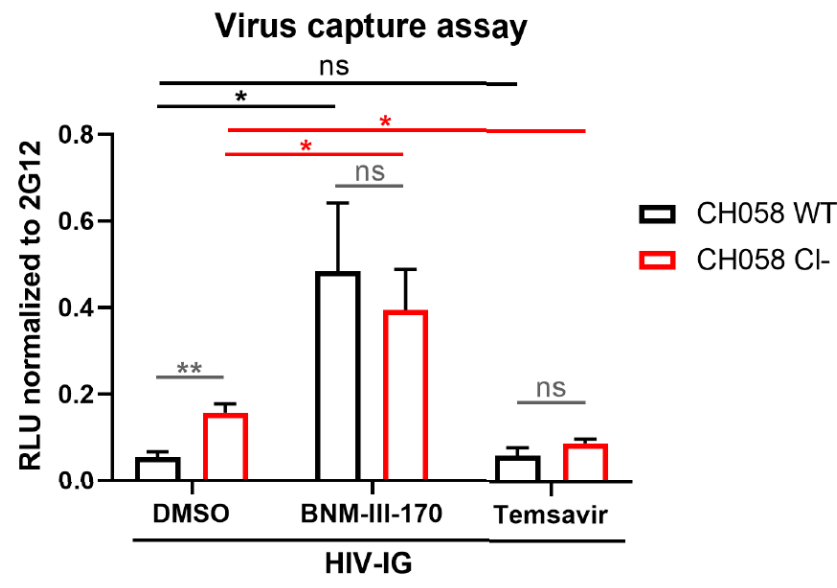

Figure 2. Virions displaying uncleaved Env are better recognized by nnAbs. (A) Viral infectivity was assessed by incubating TZM-bl target cells with HIV-1 CH058 virions expressing the wild-type (WT) or cleavage-deficient (Cl-) Env glycoprotein for $48 \mathrm{~h}$. Viral preparations were normalized according to reverse transcriptase activity. (B) VSV-G-pseudotyped viral particles encoding the luciferase gene (Luc+) and bearing HIV-1 CH058 Env wildtype (WT) or its cleavage-deficient mutant $(\mathrm{Cl}-)$ were used to infect $293 \mathrm{~T}$ cells to determine their infectivity in a single-round infection. (C,D) These recombinant pseudovirions were further tested for virus capture by (C) a panel of anti-Env bNAbs (PGT126, PG9, PGT151, VRC34, VRC03) and nnAbs (19b, F240, 17b, A32, C11) or (D) HIV-IG. RLU values obtained using the different antibodies were normalized to the signal obtained with the conformation-independent 2G12 mAb. Data shown are the mean \pm SEM from at least three independent experiments. Statistical significance was tested using an unpaired $t$-test or a Mann-Whitney $U$-test based on statistical normality ${ }^{*} p<0.05{ }^{* *} p<0.01{ }^{* * *} p<0.001$; ${ }^{* * * *} p<0.0001$; ns, nonsignificant).

\subsection{Impact of HIV-1 Env Proteolytic Cleavage on ADCC Responses Mediated by HIV+ Plasma}

Knowing that alterations in the furin cleavage site increase the exposure of downstream conformations at the surface of infected cells and lentiviral particles, we sought to determine whether the presence of uncleaved Env at the surface of infected cells could also affect ADCC responses mediated by plasma from HIV-1-infected donors. Activated primary CD4+ T cells were infected with WT or cleavage defective $\mathrm{CH} 058$ and $\mathrm{CH} 077$ and then examined for their susceptibility to ADCC killing following incubation with plasma from 15 different chronically HIV-1-infected individuals. As expected, HIV+ plasma binding was significantly higher on infected cells expressing cleavage-deficient Env compared to WT Env (Figure 3A,B). Moreover, inhibition of Env cleavage led to strong ADCC responses, while WT-infected cells were protected from these responses mediated by HIV+ plasma (Figure 3C,D). Treatment with BNM-III-170 was found to enhance the binding 
of HIV+ plasma on both WT and Cl- mutant infected cells, consistent with its ability to expose CD4i epitopes. Accordingly, CD4mc addition induced a potent ADCC response against WT-infected cells, but marginally enhanced the ADCC response against cells expressing cleavage-deficient Env, suggesting that CD4i epitope exposure by uncleaved Env is sufficient to trigger the elimination of infected cells by ADCC. Conversely, the addition of State 1-stabilizing molecule Temsavir protected $\mathrm{Cl}-$ expressing cells from ADCC by decreasing the binding of HIV+ plasma to uncleaved Env (Figure 3A-D). Of note, Temsavir did not impact HIV+ plasma mediated ADCC against WT infected cells since they are known to already express the Env in the "closed" conformation [26,35-37,40,60,61,86,91,92]. Altogether, our results demonstrate the importance for HIV-1 to limit the presence of Env gp160 precursor at the surface of infected cells to evade nnAbs-mediated ADCC responses.

A

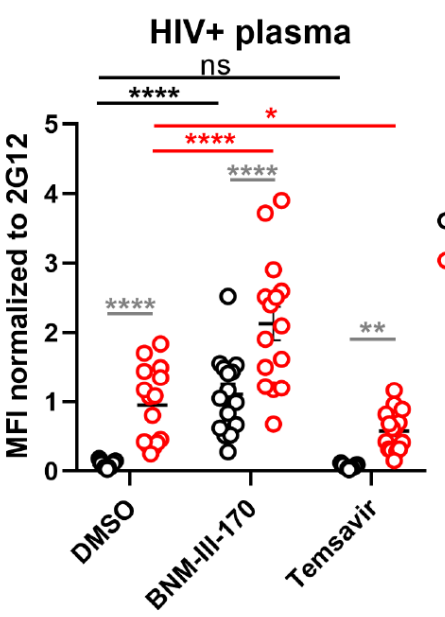

C

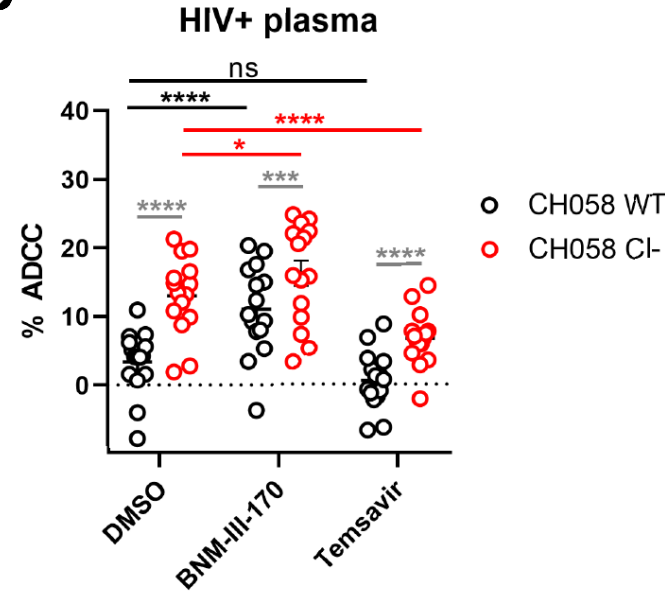

B

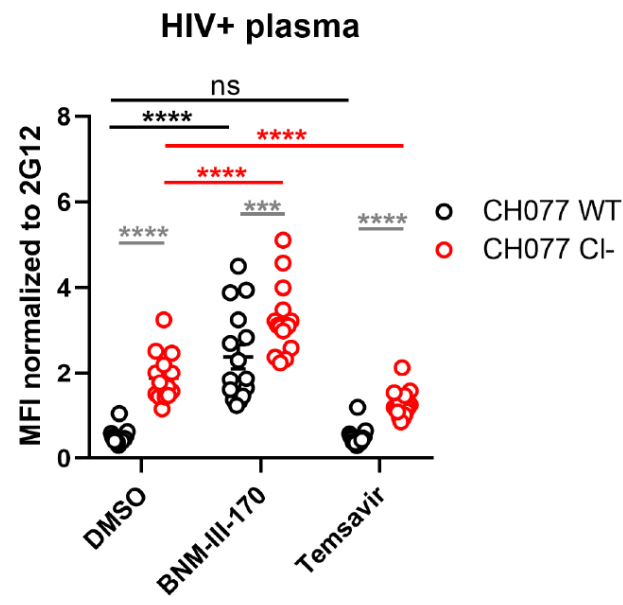

D

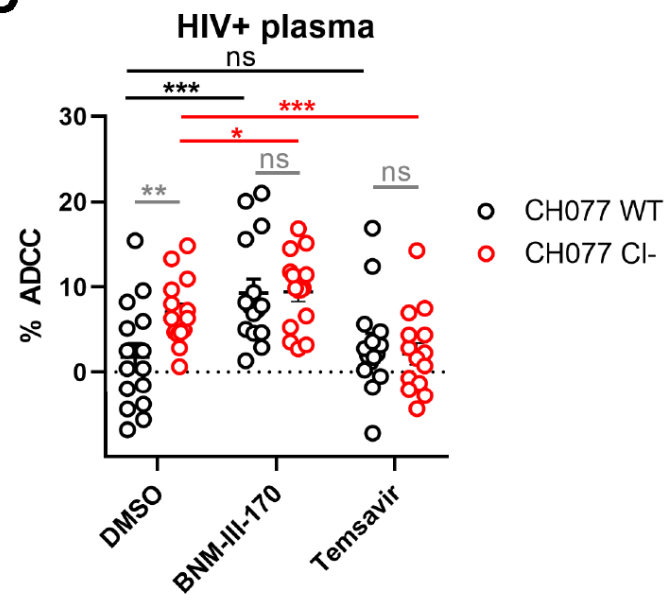

Figure 3. Env cleavage protects HIV-1-infected cells from ADCC mediated by HIV+ plasma. (A,B) Cell surface staining of primary CD4+T cells infected with primary HIV-1 viruses (A) CH058 and (B) CH077 WT or their cleavage-deficient $(\mathrm{Cl}-)$ variants using plasma from 15 different HIV-1-infected individuals in the presence of $50 \mu \mathrm{M}$ of CD4mc BNM-III-170, conformational blocker Temsavir or an equivalent volume of the vehicle (DMSO). The graphs show the MFI obtained on the infected (p24+) cell population. (C,D) Primary CD4+ T cells infected with (C) CH058 and (D) CH077 viruses were also used as target cells, and autologous PBMCs were used as effector cells in a FACS-based ADCC assay. The graphs shown represent the percentages of ADCC mediated by 15 different HIV+ plasma in the presence of $50 \mu \mathrm{M}$ of CD4mc BNM-III-170, attachment inhibitor Temsavir or an equivalent volume of the vehicle (DMSO). All results were obtained using cells from at least three different donors. Error bars indicate the means \pm SEM. Statistical significance was tested using a repeated measures one-way ANOVA with a Holm-Sidak post-test $\left({ }^{*} p<0.05\right.$; ${ }^{* *} p<0.01$; ${ }^{* * *} p<0.001$; ${ }^{* * *} p<0.0001$; ns, nonsignificant). 


\section{Discussion}

In this study, we show that uncleaved HIV-1 Env trimers display conformational flexibility which favors the sampling of downstream "more open" conformations at the surface of infected cells and pseudoviral particles. Cell-surface expression of uncleaved gp160 leads to an efficient recognition of infected cells by non-neutralizing CD4i antibodies naturally present in plasma from HIV-1-infected individuals and as a consequence, leads to a significantly higher susceptibility to ADCC responses. Conversely, efficient cleavage by endogenous furin allows Env trimers to sample a metastable "closed" conformation (State 1), thus protecting HIV-1-infected cells from ADCC responses mediated by HIV+ plasma. Beyond the well-established role of furin cleavage on viral infectivity, efficient proteolytic cleavage of Env trimers thus appears to allow HIV-1 to evade humoral immune responses. These results are important in the context of recent findings showing that several interferon-inducible cellular antiviral factors affect Env gp160 precursor processing [93-97]. Among them, IFITM proteins impair Env cleavage through direct interaction with Env, while GBP2 and GBP5 restrict furin protease activity $[93,96]$. The antiviral activity of both families of proteins can be overcome by HIV-1 through Env substitutions or by increasing Env expression through the deletion of the accessory Vpu protein, respectively [97-100].

According to the Los Alamos National Laboratory HIV sequence database, very few mutations are naturally found in the furin cleavage site, especially for the basic residues found at positions 508, 510, and 511 which are more than $99.7 \%$ conserved. Given the importance of an effective Env cleavage to generate infectious viral particles, therapeutic interventions designed to specifically inhibit this proteolytic cleavage could result in a loss in infectivity with a concomitant increase in ADCC responses against infected cells. A recent study has shown that conformational blockers, such as Temsavir, can interfere with proper Env cleavage by reducing its conformational flexibility [63]. Additional drugs inhibiting directly the furin protease activity, including the synthetic peptide Dec-RVKR$\mathrm{CMK}$ and the serine protease inhibitor $\alpha_{1}-\mathrm{PDX}$, are also being investigated, but their in vivo efficacy and toxicity remain to be determined [12,13,101-105]. If these broad-spectrum inhibitors end up being well-tolerated and exhibit good pharmacokinetic properties, they may also be useful as therapeutics against other viral infections, including Influenza A, Ebola, Respiratory syncytial virus (RSV), and SARS-CoV-2, where the acquisition of a furin cleavage site in the respective fusion glycoproteins appears to confer a higher level of infectivity [106-110].

Author Contributions: J.P. and A.F. conceived the study; J.P. and A.F. designed experimental approaches; J.P., H.M., D.V. and A.F. performed, analyzed, and interpreted the experiments; H.-C.C., B.H.H. and A.B.S.III supplied novel/unique reagents; J.P. and A.F. wrote the paper. All authors have read and agreed to the published version of the manuscript.

Funding: This study was supported by grants from the National Institutes of Health to A.F. (R01 AI148379, R01 AI129769, and R01 AI150322) and BHH (R01 AI162646 and UM1 AI164570). Support for this work was also provided by P01 GM56550/AI150471 to A.B.S. and A.F. This work was partially supported by 1UM1AI164562-01, co-funded by National Heart, Lung and Blood Institute, National Institute of Diabetes and Digestive and Kidney Diseases, National Institute of Neurological Disorders and Stroke, National Institute on Drug Abuse and the National Institute of Allergy and Infectious Diseases, by a CIHR Foundation grant \#352417, a CIHR Team Grant \#422148 and a Canada Foundation for Innovation grant \#41027 to A.F. A.F. is the recipient of a Canada Research Chair on Retroviral Entry \#RCHS0235 950-232424. J.P. is the recipient of a CIHR doctoral fellowship. The funders had no role in study design, data collection and analysis, decision to publish, or preparation of the manuscript.

Institutional Review Board Statement: The study was conducted according to the guidelines of the Declaration of Helsinki and approved by the CRCHUM Institutional Review Board (ethics committee, approval number CE 16.164-CA).

Informed Consent Statement: Informed consent was obtained from all subjects involved in the study.

Data Availability Statement: All data are contained within the article. 
Acknowledgments: The authors thank the CRCHUM BSL3 and Flow Cytometry Platforms for technical assistance, Mario Legault from the FRQS AIDS and Infectious Diseases network for cohort coordination and clinical samples. We thank Michel Nussenzweig (The Rockefeller University) for 10-1074 and John Mascola (VRC, NIAID) for VRC34. The graphical abstract was prepared using illustrations from BioRender.com.

Conflicts of Interest: The authors declare no competing interest.

\section{References}

1. Earl, P.L.; Doms, R.W.; Moss, B. Oligomeric structure of the human immunodeficiency virus type 1 envelope glycoprotein. Proc. Natl. Acad. Sci. USA 1990, 87, 648-652. [CrossRef]

2. Earl, P.L.; Moss, B.; Doms, R.W. Folding, interaction with GRP78-BiP, assembly, and transport of the human immunodeficiency virus type 1 envelope protein. J. Virol. 1991, 65, 2047-2055. [CrossRef] [PubMed]

3. Kantanen, M.L.; Leinikki, P.; Kuismanen, E. Endoproteolytic cleavage of HIV-1 gp160 envelope precursor occurs after exit from the trans-Golgi network (TGN). Arch. Virol. 1995, 140, 1441-1449. [CrossRef]

4. Qi, M.; Williams, J.A.; Chu, H.; Chen, X.; Wang, J.J.; Ding, L.; Akhirome, E.; Wen, X.; Lapierre, L.A.; Goldenring, J.R.; et al. Rab11-FIP1C and Rab14 direct plasma membrane sorting and particle incorporation of the HIV-1 envelope glycoprotein complex. PLoS Pathog. 2013, 9, e1003278. [CrossRef] [PubMed]

5. Kirschman, J.; Qi, M.; Ding, L.; Hammonds, J.; Dienger-Stambaugh, K.; Wang, J.J.; Lapierre, L.A.; Goldenring, J.R.; Spearman, P. HIV-1 Envelope Glycoprotein Trafficking through the Endosomal Recycling Compartment Is Required for Particle Incorporation. J. Virol. 2018, 92. [CrossRef] [PubMed]

6. Freed, E.O.; Myers, D.J.; Risser, R. Mutational analysis of the cleavage sequence of the human immunodeficiency virus type 1 envelope glycoprotein precursor gp160. J. Virol. 1989, 63, 4670-4675. [CrossRef] [PubMed]

7. Bosch, V.; Pawlita, M. Mutational analysis of the human immunodeficiency virus type 1 env gene product proteolytic cleavage site. J. Virol. 1990, 64, 2337-2344. [CrossRef]

8. McCune, J.M.; Rabin, L.B.; Feinberg, M.B.; Lieberman, M.; Kosek, J.C.; Reyes, G.R.; Weissman, I.L. Endoproteolytic cleavage of gp160 is required for the activation of human immunodeficiency virus. Cell 1988, 53, 55-67. [CrossRef]

9. Leonard, C.K.; Spellman, M.W.; Riddle, L.; Harris, R.J.; Thomas, J.N.; Gregory, T.J. Assignment of intrachain disulfide bonds and characterization of potential glycosylation sites of the type 1 recombinant human immunodeficiency virus envelope glycoprotein (gp120) expressed in Chinese hamster ovary cells. J. Biol. Chem. 1990, 265, 10373-10382. [CrossRef]

10. Bernstein, H.B.; Tucker, S.P.; Hunter, E.; Schutzbach, J.S.; Compans, R.W. Human immunodeficiency virus type 1 envelope glycoprotein is modified by O-linked oligosaccharides. J. Virol. 1994, 68, 463-468. [CrossRef]

11. Dewar, R.L.; Vasudevachari, M.B.; Natarajan, V.; Salzman, N.P. Biosynthesis and processing of human immunodeficiency virus type 1 envelope glycoproteins: Effects of monensin on glycosylation and transport. J. Virol. 1989, 63, 2452-2456. [CrossRef]

12. Hallenberger, S.; Bosch, V.; Angliker, H.; Shaw, E.; Klenk, H.D.; Garten, W. Inhibition of furin-mediated cleavage activation of HIV-1 glycoprotein gp160. Nature 1992, 360, 358-361. [CrossRef] [PubMed]

13. Decroly, E.; Vandenbranden, M.; Ruysschaert, J.M.; Cogniaux, J.; Jacob, G.S.; Howard, S.C.; Marshall, G.; Kompelli, A.; Basak, A.; Jean, F.; et al. The convertases furin and PC1 can both cleave the human immunodeficiency virus (HIV)-1 envelope glycoprotein gp160 into gp120 (HIV-1 SU) and gp41 (HIV-I TM). J. Biol. Chem. 1994, 269, 12240-12247. [CrossRef]

14. Decroly, E.; Wouters, S.; Di Bello, C.; Lazure, C.; Ruysschaert, J.M.; Seidah, N.G. Identification of the paired basic convertases implicated in HIV gp160 processing based on in vitro assays and expression in CD4(+) cell lines. J. Biol. Chem. 1996, 271, 30442-30450. [CrossRef]

15. Decroly, E.; Benjannet, S.; Savaria, D.; Seidah, N.G. Comparative functional role of PC7 and furin in the processing of the HIV envelope glycoprotein gp160. FEBS Lett. 1997, 405, 68-72. [CrossRef]

16. Molloy, S.S.; Thomas, L.; VanSlyke, J.K.; Stenberg, P.E.; Thomas, G. Intracellular trafficking and activation of the furin proprotein convertase: Localization to the TGN and recycling from the cell surface. EMBO J. 1994, 13, 18-33. [CrossRef]

17. Dubay, J.W.; Dubay, S.R.; Shin, H.J.; Hunter, E. Analysis of the cleavage site of the human immunodeficiency virus type 1 glycoprotein: Requirement of precursor cleavage for glycoprotein incorporation. J. Virol. 1995, 69, 4675-4682. [CrossRef] [PubMed]

18. Herrera, C.; Klasse, P.J.; Michael, E.; Kake, S.; Barnes, K.; Kibler, C.W.; Campbell-Gardener, L.; Si, Z.; Sodroski, J.; Moore, J.P.; et al. The impact of envelope glycoprotein cleavage on the antigenicity, infectivity, and neutralization sensitivity of Env-pseudotyped human immunodeficiency virus type 1 particles. Virology 2005, 338, 154-172. [CrossRef] [PubMed]

19. Pasquato, A.; Dettin, M.; Basak, A.; Gambaretto, R.; Tonin, L.; Seidah, N.G.; Di Bello, C. Heparin enhances the furin cleavage of HIV-1 gp160 peptides. FEBS Lett. 2007, 581, 5807-5813. [CrossRef]

20. Munro, J.B.; Gorman, J.; Ma, X.; Zhou, Z.; Arthos, J.; Burton, D.R.; Koff, W.C.; Courter, J.R.; Smith, A.B., III; Kwong, P.D.; et al. Conformational dynamics of single HIV-1 envelope trimers on the surface of native virions. Science 2014, 346, 759-763. [CrossRef]

21. Ma, X.; Lu, M.; Gorman, J.; Terry, D.S.; Hong, X.; Zhou, Z.; Zhao, H.; Altman, R.B.; Arthos, J.; Blanchard, S.C.; et al. HIV-1 Env trimer opens through an asymmetric intermediate in which individual protomers adopt distinct conformations. eLife $2018,7$. [CrossRef] [PubMed] 
22. Lu, M.; Ma, X.; Castillo-Menendez, L.R.; Gorman, J.; Alsahafi, N.; Ermel, U.; Terry, D.S.; Chambers, M.; Peng, D.; Zhang, B.; et al. Associating HIV-1 envelope glycoprotein structures with states on the virus observed by smFRET. Nature 2019. [CrossRef]

23. Li, Z.; Li, W.; Lu, M.; Bess, J., Jr.; Chao, C.W.; Gorman, J.; Terry, D.S.; Zhang, B.; Zhou, T.; Blanchard, S.C.; et al. Subnanometer structures of HIV-1 envelope trimers on aldrithiol-2-inactivated virus particles. Nat. Struct. Mol. Biol. 2020, 27, 726-734. [CrossRef]

24. Stadtmueller, B.M.; Bridges, M.D.; Dam, K.M.; Lerch, M.T.; Huey-Tubman, K.E.; Hubbell, W.L.; Bjorkman, P.J. DEER Spectroscopy Measurements Reveal Multiple Conformations of HIV-1 SOSIP Envelopes that Show Similarities with Envelopes on Native Virions. Immunity 2018, 49, 235-246.e234. [CrossRef] [PubMed]

25. Finzi, A.; Xiang, S.H.; Pacheco, B.; Wang, L.; Haight, J.; Kassa, A.; Danek, B.; Pancera, M.; Kwong, P.D.; Sodroski, J. Topological layers in the HIV-1 gp120 inner domain regulate gp41 interaction and CD4-triggered conformational transitions. Mol. Cell 2010, 37, 656-667. [CrossRef]

26. Veillette, M.; Desormeaux, A.; Medjahed, H.; Gharsallah, N.E.; Coutu, M.; Baalwa, J.; Guan, Y.; Lewis, G.; Ferrari, G.; Hahn, B.H.; et al. Interaction with cellular CD4 exposes HIV-1 envelope epitopes targeted by antibody-dependent cell-mediated cytotoxicity. J. Virol. 2014, 88, 2633-2644. [CrossRef]

27. Decker, J.M.; Bibollet-Ruche, F.; Wei, X.; Wang, S.; Levy, D.N.; Wang, W.; Delaporte, E.; Peeters, M.; Derdeyn, C.A.; Allen, S.; et al. Antigenic conservation and immunogenicity of the HIV coreceptor binding site. J. Exp. Med. 2005, 201, 1407-1419. [CrossRef]

28. Tomaras, G.D.; Yates, N.L.; Liu, P.; Qin, L.; Fouda, G.G.; Chavez, L.L.; Decamp, A.C.; Parks, R.J.; Ashley, V.C.; Lucas, J.T.; et al. Initial B-cell responses to transmitted human immunodeficiency virus type 1: Virion-binding immunoglobulin $\mathrm{M}$ (IgM) and IgG antibodies followed by plasma anti-gp41 antibodies with ineffective control of initial viremia. J. Virol. 2008, 82, 12449-12463. [CrossRef]

29. Tomaras, G.D.; Haynes, B.F. HIV-1-specific antibody responses during acute and chronic HIV-1 infection. Curr. Opin. HIV AIDS 2009, 4, 373-379. [CrossRef] [PubMed]

30. Davis, K.L.; Gray, E.S.; Moore, P.L.; Decker, J.M.; Salomon, A.; Montefiori, D.C.; Graham, B.S.; Keefer, M.C.; Pinter, A.; Morris, L.; et al. High titer HIV-1 V3-specific antibodies with broad reactivity but low neutralizing potency in acute infection and following vaccination. Virology 2009, 387, 414-426. [CrossRef]

31. Madani, N.; Princiotto, A.M.; Easterhoff, D.; Bradley, T.; Luo, K.; Williams, W.B.; Liao, H.X.; Moody, M.A.; Phad, G.E.; Vazquez Bernat, N.; et al. Antibodies Elicited by Multiple Envelope Glycoprotein Immunogens in Primates Neutralize Primary Human Immunodeficiency Viruses (HIV-1) Sensitized by CD4-Mimetic Compounds. J. Virol. 2016, 90, 5031-5046. [CrossRef] [PubMed]

32. Madani, N.; Princiotto, A.M.; Mach, L.; Ding, S.; Prevost, J.; Richard, J.; Hora, B.; Sutherland, L.; Zhao, C.A.; Conn, B.P.; et al. A CD4-mimetic compound enhances vaccine efficacy against stringent immunodeficiency virus challenge. Nat. Commun. 2018, 9 , 2363. [CrossRef]

33. Ferrari, G.; Pollara, J.; Kozink, D.; Harms, T.; Drinker, M.; Freel, S.; Moody, M.A.; Alam, S.M.; Tomaras, G.D.; Ochsenbauer, C.; et al. An HIV-1 gp120 envelope human monoclonal antibody that recognizes a C1 conformational epitope mediates potent antibody-dependent cellular cytotoxicity (ADCC) activity and defines a common ADCC epitope in human HIV-1 serum. J. Virol. 2011, 85, 7029-7036. [CrossRef] [PubMed]

34. Guan, Y.; Pazgier, M.; Sajadi, M.M.; Kamin-Lewis, R.; Al-Darmarki, S.; Flinko, R.; Lovo, E.; Wu, X.; Robinson, J.E.; Seaman, M.S.; et al. Diverse specificity and effector function among human antibodies to HIV-1 envelope glycoprotein epitopes exposed by CD4 binding. Proc. Natl. Acad. Sci. USA 2013, 110, E69-E78. [CrossRef] [PubMed]

35. Veillette, M.; Coutu, M.; Richard, J.; Batraville, L.A.; Dagher, O.; Bernard, N.; Tremblay, C.; Kaufmann, D.E.; Roger, M.; Finzi, A. The HIV-1 gp120 CD4-Bound Conformation Is Preferentially Targeted by Antibody-Dependent Cellular Cytotoxicity-Mediating Antibodies in Sera from HIV-1-Infected Individuals. J. Virol. 2015, 89, 545-551. [CrossRef]

36. Richard, J.; Veillette, M.; Brassard, N.; Iyer, S.S.; Roger, M.; Martin, L.; Pazgier, M.; Schon, A.; Freire, E.; Routy, J.P.; et al. CD4 mimetics sensitize HIV-1-infected cells to ADCC. Proc. Natl. Acad. Sci. USA 2015, 112, E2687-E2694. [CrossRef]

37. Ding, S.; Veillette, M.; Coutu, M.; Prevost, J.; Scharf, L.; Bjorkman, P.J.; Ferrari, G.; Robinson, J.E.; Sturzel, C.; Hahn, B.H.; et al. A Highly Conserved Residue of the HIV-1 gp120 Inner Domain Is Important for Antibody-Dependent Cellular Cytotoxicity Responses Mediated by Anti-cluster A Antibodies. J. Virol. 2016, 90, 2127-2134. [CrossRef]

38. Ding, S.; Verly, M.M.; Princiotto, A.; Melillo, B.; Moody, T.; Bradley, T.; Easterhoff, D.; Roger, M.; Hahn, B.H.; Madani, N.; et al. Small Molecule CD4-Mimetics Sensitize HIV-1-infected Cells to ADCC by Antibodies Elicited by Multiple Envelope Glycoprotein Immunogens in Non-Human Primates. AIDS Res. Hum. Retrovir. 2016. [CrossRef]

39. Veillette, M.; Coutu, M.; Richard, J.; Batraville, L.A.; Desormeaux, A.; Roger, M.; Finzi, A. Conformational evaluation of HIV-1 trimeric envelope glycoproteins using a cell-based ELISA assay. J. Vis. Exp. 2014. [CrossRef]

40. Alsahafi, N.; Bakouche, N.; Kazemi, M.; Richard, J.; Ding, S.; Bhattacharyya, S.; Das, D.; Anand, S.P.; Prevost, J.; Tolbert, W.D.; et al. An Asymmetric Opening of HIV-1 Envelope Mediates Antibody-Dependent Cellular Cytotoxicity. Cell Host. Microbe. 2019, 25, 578-587.e575. [CrossRef] [PubMed]

41. Willey, R.L.; Maldarelli, F.; Martin, M.A.; Strebel, K. Human immunodeficiency virus type 1 Vpu protein induces rapid degradation of CD4. J. Virol. 1992, 66, 7193-7200. [CrossRef] [PubMed]

42. Rhee, S.S.; Marsh, J.W. Human immunodeficiency virus type 1 Nef-induced down-modulation of CD4 is due to rapid internalization and degradation of surface CD4. J. Virol. 1994, 68, 5156-5163. [CrossRef] [PubMed] 
43. Madani, N.; Schon, A.; Princiotto, A.M.; Lalonde, J.M.; Courter, J.R.; Soeta, T.; Ng, D.; Wang, L.; Brower, E.T.; Xiang, S.H.; et al. Small-molecule CD4 mimics interact with a highly conserved pocket on HIV-1 gp120. Structure 2008, 16, 1689-1701. [CrossRef] [PubMed]

44. Madani, N.; Princiotto, A.M.; Schon, A.; LaLonde, J.; Feng, Y.; Freire, E.; Park, J.; Courter, J.R.; Jones, D.M.; Robinson, J.; et al. CD4-mimetic small molecules sensitize human immunodeficiency virus to vaccine-elicited antibodies. J. Virol. 2014, 88, $6542-6555$. [CrossRef]

45. Madani, N.; Princiotto, A.M.; Zhao, C.; Jahanbakhshsefidi, F.; Mertens, M.; Herschhorn, A.; Melillo, B.; Smith, A.B., III; Sodroski, J. Activation and Inactivation of Primary Human Immunodeficiency Virus Envelope Glycoprotein Trimers by CD4-Mimetic Compounds. J. Virol. 2017, 91. [CrossRef] [PubMed]

46. Princiotto, A.M.; Vrbanac, V.D.; Melillo, B.; Park, J.; Tager, A.M.; Smith, A.B., III; Sodroski, J.; Madani, N. A Small-Molecule CD4-Mimetic Compound Protects Bone Marrow-Liver-Thymus Humanized Mice From HIV-1 Infection. J. Infect. Dis. 2018, 218, 471-475. [CrossRef] [PubMed]

47. Lee, W.S.; Richard, J.; Lichtfuss, M.; Smith, A.B., III; Park, J.; Courter, J.R.; Melillo, B.N.; Sodroski, J.G.; Kaufmann, D.E.; Finzi, A.; et al. Antibody-Dependent Cellular Cytotoxicity against Reactivated HIV-1-Infected Cells. J. Virol. 2015, 90, 2021-2030. [CrossRef]

48. Richard, J.; Pacheco, B.; Gohain, N.; Veillette, M.; Ding, S.; Alsahafi, N.; Tolbert, W.D.; Prevost, J.; Chapleau, J.P.; Coutu, M.; et al. Co-receptor Binding Site Antibodies Enable CD4-Mimetics to Expose Conserved Anti-cluster A ADCC Epitopes on HIV-1 Envelope Glycoproteins. EBioMedicine 2016, 12, 208-218. [CrossRef]

49. Anand, S.P.; Prevost, J.; Baril, S.; Richard, J.; Medjahed, H.; Chapleau, J.P.; Tolbert, W.D.; Kirk, S.; Smith, A.B., III; Wines, B.D.; et al. Two Families of Env Antibodies Efficiently Engage Fc-Gamma Receptors and Eliminate HIV-1-Infected Cells. J. Virol. 2019, 93. [CrossRef]

50. Ding, S.; Grenier, M.C.; Tolbert, W.D.; Vezina, D.; Sherburn, R.; Richard, J.; Prevost, J.; Chapleau, J.P.; Gendron-Lepage, G.; Medjahed, H.; et al. A New Family of Small-Molecule CD4-Mimetic Compounds Contacts Highly Conserved Aspartic Acid 368 of HIV-1 gp120 and Mediates Antibody-Dependent Cellular Cytotoxicity. J. Virol. 2019, 93. [CrossRef] [PubMed]

51. Prevost, J.; Tolbert, W.D.; Medjahed, H.; Sherburn, R.T.; Madani, N.; Zoubchenok, D.; Gendron-Lepage, G.; Gaffney, A.E.; Grenier, M.C.; Kirk, S.; et al. The HIV-1 Env gp120 Inner Domain Shapes the Phe43 Cavity and the CD4 Binding Site. mBio $2020,11$. [CrossRef]

52. Vezina, D.; Gong, S.Y.; Tolbert, W.D.; Ding, S.; Nguyen, D.; Richard, J.; Gendron-Lepage, G.; Melillo, B.; Smith, A.B., III; Pazgier, M.; et al. Stabilizing the HIV-1 envelope glycoprotein State 2A conformation. J. Virol. 2020. [CrossRef]

53. Rajashekar, J.K.; Richard, J.; Beloor, J.; Prevost, J.; Anand, S.P.; Beaudoin-Bussieres, G.; Shan, L.; Herndler-Brandstetter, D.; Gendron-Lepage, G.; Medjahed, H.; et al. Modulating HIV-1 envelope glycoprotein conformation to decrease the HIV-1 reservoir. Cell Host Microbe 2021, 29, 904-916.e906. [CrossRef]

54. Zou, S.; Zhang, S.; Gaffney, A.; Ding, H.; Lu, M.; Grover, J.R.; Farrell, M.; Nguyen, H.T.; Zhao, C.; Anang, S.; et al. LongActing BMS-378806 Analogues Stabilize the State-1 Conformation of the Human Immunodeficiency Virus (HIV-1) Envelope Glycoproteins. J. Virol. 2020. [CrossRef]

55. Lu, M.; Ma, X.; Reichard, N.; Terry, D.S.; Arthos, J.; Smith, A.B., III; Sodroski, J.G.; Blanchard, S.C.; Mothes, W. Shedding-Resistant HIV-1 Envelope Glycoproteins Adopt Downstream Conformations That Remain Responsive to Conformation-Preferring Ligands. J. Virol. 2020, 94. [CrossRef]

56. Xiang, S.H.; Kwong, P.D.; Gupta, R.; Rizzuto, C.D.; Casper, D.J.; Wyatt, R.; Wang, L.; Hendrickson, W.A.; Doyle, M.L.; Sodroski, J. Mutagenic stabilization and/or disruption of a CD4-bound state reveals distinct conformations of the human immunodeficiency virus type 1 gp120 envelope glycoprotein. J. Virol. 2002, 76, 9888-9899. [CrossRef] [PubMed]

57. Herschhorn, A.; Ma, X.; Gu, C.; Ventura, J.D.; Castillo-Menendez, L.; Melillo, B.; Terry, D.S.; Smith, A.B., III; Blanchard, S.C.; Munro, J.B.; et al. Release of gp120 Restraints Leads to an Entry-Competent Intermediate State of the HIV-1 Envelope Glycoproteins. MBio 2016, 7. [CrossRef]

58. Desormeaux, A.; Coutu, M.; Medjahed, H.; Pacheco, B.; Herschhorn, A.; Gu, C.; Xiang, S.H.; Mao, Y.; Sodroski, J.; Finzi, A. The highly conserved layer-3 component of the HIV-1 gp120 inner domain is critical for CD4-required conformational transitions. $J$. Virol. 2013, 87, 2549-2562. [CrossRef] [PubMed]

59. Vilmen, G.; Smith, A.C.; Benet, H.C.; Shukla, R.K.; Larue, R.C.; Herschhorn, A.; Sharma, A. Conformation of HIV-1 Envelope governs rhesus CD4 usage and simian-human immunodeficiency virus replication. bioRxiv 2021. [CrossRef]

60. Prevost, J.; Zoubchenok, D.; Richard, J.; Veillette, M.; Pacheco, B.; Coutu, M.; Brassard, N.; Parsons, M.S.; Ruxrungtham, K.; Bunupuradah, T; et al. Influence of the Envelope gp120 Phe 43 Cavity on HIV-1 Sensitivity to Antibody-Dependent Cell-Mediated Cytotoxicity Responses. J. Virol. 2017, 91. [CrossRef] [PubMed]

61. Prevost, J.; Richard, J.; Ding, S.; Pacheco, B.; Charlebois, R.; Hahn, B.H.; Kaufmann, D.E.; Finzi, A. Envelope glycoproteins sampling states $2 / 3$ are susceptible to ADCC by sera from HIV-1-infected individuals. Virology 2018, 515, 38-45. [CrossRef] [PubMed]

62. Castillo-Menendez, L.R.; Witt, K.; Espy, N.; Princiotto, A.; Madani, N.; Pacheco, B.; Finzi, A.; Sodroski, J. Comparison of Uncleaved and Mature Human Immunodeficiency Virus Membrane Envelope Glycoprotein Trimers. J. Virol. 2018, 92. [CrossRef]

63. Zhang, S.; Wang, K.; Wang, W.L.; Nguyen, H.T.; Chen, S.; Lu, M.; Go, E.P.; Ding, H.; Steinbock, R.T.; Desaire, H.; et al. Asymmetric structures and conformational plasticity of the uncleaved full-length human immunodeficiency virus (HIV-1) envelope glycoprotein trimer. J. Virol. 2021. [CrossRef] 
64. Ringe, R.P.; Sanders, R.W.; Yasmeen, A.; Kim, H.J.; Lee, J.H.; Cupo, A.; Korzun, J.; Derking, R.; van Montfort, T.; Julien, J.P.; et al. Cleavage strongly influences whether soluble HIV-1 envelope glycoprotein trimers adopt a native-like conformation. Proc. Natl. Acad. Sci. USA 2013, 110, 18256-18261. [CrossRef] [PubMed]

65. Chakrabarti, B.K.; Pancera, M.; Phogat, S.; O’Dell, S.; McKee, K.; Guenaga, J.; Robinson, J.; Mascola, J.; Wyatt, R.T. HIV type 1 Env precursor cleavage state affects recognition by both neutralizing and nonneutralizing gp41 antibodies. AIDS Res. Hum. Retrovir. 2011, 27, 877-887. [CrossRef]

66. Fontaine, J.; Chagnon-Choquet, J.; Valcke, H.S.; Poudrier, J.; Roger, M. High expression levels of B lymphocyte stimulator (BLyS) by dendritic cells correlate with HIV-related B-cell disease progression in humans. Blood 2011, 117, 145-155. [CrossRef]

67. Fontaine, J.; Coutlee, F.; Tremblay, C.; Routy, J.P.; Poudrier, J.; Roger, M. HIV infection affects blood myeloid dendritic cells after successful therapy and despite nonprogressing cl.inical disease. J. Infect. Dis. 2009, 199, 1007-1018. [CrossRef] [PubMed]

68. International, H.I.V.C.S.; Pereyra, F.; Jia, X.; McLaren, P.J.; Telenti, A.; de Bakker, P.I.; Walker, B.D.; Ripke, S.; Brumme, C.J.; Pulit, S.L.; et al. The major genetic determinants of HIV-1 control affect HLA class I peptide presentation. Science 2010, 330, 1551-1557. [CrossRef]

69. Kamya, P.; Boulet, S.; Tsoukas, C.M.; Routy, J.P.; Thomas, R.; Cote, P.; Boulassel, M.R.; Baril, J.G.; Kovacs, C.; Migueles, S.A.; et al. Receptor-ligand requirements for increased NK cell polyfunctional potential in slow progressors infected with HIV-1 coexpressing KIR3DL1*h/*y and HLA-B57. J. Virol. 2011, 85, 5949-5960. [CrossRef]

70. Peretz, Y.; Ndongala, M.L.; Boulet, S.; Boulassel, M.R.; Rouleau, D.; Cote, P.; Longpre, D.; Routy, J.P.; Falutz, J.; Tremblay, C.; et al. Functional T cell subsets contribute differentially to HIV peptide-specific responses within infected individuals: Correlation of these functional $\mathrm{T}$ cell subsets with markers of disease progression. Clin. Immunol. 2007, 124, 57-68. [CrossRef]

71. Platt, E.J.; Wehrly, K.; Kuhmann, S.E.; Chesebro, B.; Kabat, D. Effects of CCR5 and CD4 cell surface concentrations on infections by macrophagetropic isolates of human immunodeficiency virus type 1. J. Virol. 1998, 72, 2855-2864. [CrossRef]

72. Chen, J.; Park, J.; Kirk, S.M.; Chen, H.C.; Li, X.; Lippincott, D.J.; Melillo, B.; Smith, A.B., III. Development of an Effective Scalable Enantioselective Synthesis of the HIV-1 Entry Inhibitor BNM-III-170 as the Bis-Trifluoroacetate Salt. Org. Process. Res. Dev. 2019, 23, 2464-2469. [CrossRef]

73. Emi, N.; Friedmann, T.; Yee, J.K. Pseudotype formation of murine leukemia virus with the G protein of vesicular stomatitis virus. J. Virol. 1991, 65, 1202-1207. [CrossRef] [PubMed]

74. Salazar-Gonzalez, J.F.; Salazar, M.G.; Keele, B.F.; Learn, G.H.; Giorgi, E.E.; Li, H.; Decker, J.M.; Wang, S.; Baalwa, J.; Kraus, M.H.; et al. Genetic identity, biological phenotype, and evolutionary pathways of transmitted/founder viruses in acute and early HIV-1 infection. J. Exp. Med. 2009, 206, 1273-1289. [CrossRef]

75. Ochsenbauer, C.; Edmonds, T.G.; Ding, H.; Keele, B.F.; Decker, J.; Salazar, M.G.; Salazar-Gonzalez, J.F.; Shattock, R.; Haynes, B.F.; Shaw, G.M.; et al. Generation of Transmitted/Founder HIV-1 Infectious Molecular Clones and Characterization of Their Replication Capacity in CD4 T Lymphocytes an.nd Monocyte-Derived Macrophages. J. Virol. 2012, 86, 2715-2728. [CrossRef]

76. Parrish, N.F.; Gao, F.; Li, H.; Giorgi, E.E.; Barbian, H.J.; Parrish, E.H.; Zajic, L.; Iyer, S.S.; Decker, J.M.; Kumar, A.; et al. Phenotypic properties of transmitted founder HIV-1. Proc. Natl. Acad. Sci. USA 2013, 110, 6626-6633. [CrossRef] [PubMed]

77. Fenton-May, A.E.; Dibben, O.; Emmerich, T.; Ding, H.; Pfafferott, K.; Aasa-Chapman, M.M.; Pellegrino, P.; Williams, I.; Cohen, M.S.; Gao, F.; et al. Relative resistance of HIV-1 founder viruses to control by interferon-alpha. Retrovirology 2013, $10,146$. [CrossRef]

78. Rho, H.M.; Poiesz, B.; Ruscetti, F.W.; Gallo, R.C. Characterization of the reverse transcriptase from a new retrovirus (HTLV) produced by a human cutaneous T-cell lymphoma cell line. Virology 1981, 112, 355-360. [CrossRef]

79. Ding, S.; Gasser, R.; Gendron-Lepage, G.; Medjahed, H.; Tolbert, W.D.; Sodroski, J.; Pazgier, M.; Finzi, A. CD4 Incorporation into HIV-1 Viral Particles Exposes Envelope Epitopes Recognized by CD4-Induced Antibodies. J. Virol. 2019, 93. [CrossRef]

80. Si, Z.; Phan, N.; Kiprilov, E.; Sodroski, J. Effects of HIV type 1 envelope glycoprotein proteolytic processing on antigenicity. AIDS Res. Hum. Retrovir. 2003, 19, 217-226. [CrossRef]

81. Yang, X.; Kurteva, S.; Lee, S.; Sodroski, J. Stoichiometry of antibody neutralization of human immunodeficiency virus type 1. J. Virol. 2005, 79, 3500-3508. [CrossRef]

82. Brandenberg, O.F.; Magnus, C.; Rusert, P.; Regoes, R.R.; Trkola, A. Different infectivity of HIV-1 strains is linked to number of envelope trimers required for entry. PLoS Pathog. 2015, 11, e1004595. [CrossRef]

83. Stieh, D.J.; King, D.F.; Klein, K.; Aldon, Y.; McKay, P.F.; Shattock, R.J. Discrete partitioning of HIV-1 Env forms revealed by viral capture. Retrovirology 2015, 12, 81. [CrossRef] [PubMed]

84. Zhang, S.; Nguyen, H.T.; Ding, H.; Wang, J.; Zou, S.; Liu, L.; Guha, D.; Gabuzda, D.; Ho, D.D.; Kappes, J.C.; et al. Dual Pathways of Human Immunodeficiency Virus Type 1 Envelope G.Glycoprotein Trafficking Modulate the Selective Exclusion of Uncleaved Oligomers from Virions. J. Virol. 2021, 95. [CrossRef]

85. Anand, S.P.; Prévost, J.; Descôteaux-Dinelle, J.; Richard, J.; Nguyen, D.N.; Medjahed, H.; Chen, H.-C.; Smith, A.B.; Pazgier, M.; Finzi, A. HIV-1 Envelope Glycoprotein Cell Surface Localization Is Associated with Antibody-Induced Internalization. Viruses 2021, 13, 1953. [CrossRef]

86. Alsahafi, N.; Ding, S.; Richard, J.; Markle, T.; Brassard, N.; Walker, B.; Lewis, G.K.; Kaufmann, D.E.; Brockman, M.A.; Finzi, A. Nef Proteins from HIV-1 Elite Controllers Are Inefficient at Preventing Antibody-Dependent Cellular Cytotoxicity. J. Virol. 2016, 90, 2993-3002. [CrossRef] [PubMed] 
87. Aloia, R.C.; Tian, H.; Jensen, F.C. Lipid composition and fluidity of the human immunodeficiency virus envelope and host cell plasma membranes. Proc. Natl. Acad. Sci. USA 1993, 90, 5181-5185. [CrossRef]

88. Vishwanathan, S.A.; Thomas, A.; Brasseur, R.; Epand, R.F.; Hunter, E.; Epand, R.M. Large changes in the CRAC segment of gp41 of HIV do not destroy fusion activity if the segment interacts with cholesterol. Biochemistry 2008, 47, 11869-11876. [CrossRef]

89. Salimi, H.; Johnson, J.; Flores, M.G.; Zhang, M.S.; O'Malley, Y.; Houtman, J.C.; Schlievert, P.M.; Haim, H. The lipid membrane of HIV-1 stabilizes the viral envelope glycoproteins and modulates their sensitivity to antibody neutralization. J. Biol. Chem. 2020, 295, 348-362. [CrossRef]

90. Cummins, L.M.; Weinhold, K.J.; Matthews, T.J.; Langlois, A.J.; Perno, C.F.; Condie, R.M.; Allain, J.P. Preparation and characterization of an intravenous solution of IgG from human immunodeficiency virus-seropositive donors. Blood 1991, 77, $1111-1117$. [CrossRef] [PubMed]

91. Prevost, J.; Richard, J.; Medjahed, H.; Alexander, A.; Jones, J.; Kappes, J.C.; Ochsenbauer, C.; Finzi, A. Incomplete Downregulation of CD4 Expression Affects HIV-1 Env Conformation and Antibody-Dependent Cellular Cytotoxicity Responses. J. Virol. 2018, 92. [CrossRef] [PubMed]

92. Alsahafi, N.; Richard, J.; Prevost, J.; Coutu, M.; Brassard, N.; Parsons, M.S.; Kaufmann, D.E.; Brockman, M.; Finzi, A. Impaired downregulation of NKG2D ligands by Nef protein from elite controllers sensitizes HIV-1-infected cells to ADCC. J. Virol. 2017. [CrossRef]

93. Braun, E.; Hotter, D.; Koepke, L.; Zech, F.; Gross, R.; Sparrer, K.M.J.; Muller, J.A.; Pfaller, C.K.; Heusinger, E.; Wombacher, R.; et al. Guanylate-Binding Proteins 2 and 5 Exert Broad Antiviral Activity by Inhibiting Furin-Mediated Processing of Viral Envelope Proteins. Cell Rep. 2019, 27, 2092-2104.e10. [CrossRef]

94. Lodermeyer, V.; Suhr, K.; Schrott, N.; Kolbe, C.; Sturzel, C.M.; Krnavek, D.; Munch, J.; Dietz, C.; Waldmann, T.; Kirchhoff, F.; et al. 90K, an interferon-stimulated gene product, reduces the infectivity of HIV-1. Retrovirology 2013, 10, 111. [CrossRef]

95. Tada, T.; Zhang, Y.; Koyama, T.; Tobiume, M.; Tsunetsugu-Yokota, Y.; Yamaoka, S.; Fujita, H.; Tokunaga, K. MARCH8 inhibits HIV-1 infection by reducing virion incorporation of envelope glycoproteins. Nat. Med. 2015, 21, 1502-1507. [CrossRef] [PubMed]

96. Yu, J.; Li, M.; Wilkins, J.; Ding, S.; Swartz, T.H.; Esposito, A.M.; Zheng, Y.M.; Freed, E.O.; Liang, C.; Chen, B.K.; et al. IFITM Proteins Restrict HIV-1 Infection by Antagonizing the Envelope Glycoprotein. Cell Rep. 2015, 13, 145-156. [CrossRef]

97. Wang, Y.; Pan, Q.; Ding, S.; Wang, Z.; Yu, J.; Finzi, A.; Liu, S.L.; Liang, C. The V3 Loop of HIV-1 Env Determines Viral Susceptibility to IFITM3 Impairment of Viral Infectivity. J. Virol. 2017, 91. [CrossRef] [PubMed]

98. Foster, T.L.; Wilson, H.; Iyer, S.S.; Coss, K.; Doores, K.; Smith, S.; Kellam, P.; Finzi, A.; Borrow, P.; Hahn, B.H.; et al. Resistance of Transmitted Founder HIV-1 to IFITM-Mediated Restriction. Cell Host Microbe 2016, 20, 429-442. [CrossRef]

99. Drouin, A.; Migraine, J.; Durand, M.A.; Moreau, A.; Burlaud-Gaillard, J.; Beretta, M.; Roingeard, P.; Bouvin-Pley, M.; Braibant, M. Escape of HIV-1 envelope glycoprotein from the restriction of infection by IFITM3. J. Virol. 2020. [CrossRef]

100. Krapp, C.; Hotter, D.; Gawanbacht, A.; McLaren, P.J.; Kluge, S.F.; Sturzel, C.M.; Mack, K.; Reith, E.; Engelhart, S.; Ciuffi, A.; et al. Guanylate Binding Protein (GBP) 5 Is an Interferon-Inducible Inhibitor of HIV-1 Infectivity. Cell Host Microbe 2016, 19, 504-514. [CrossRef]

101. Jean, F.; Stella, K.; Thomas, L.; Liu, G.; Xiang, Y.; Reason, A.J.; Thomas, G. alpha1-Antitrypsin Portland, a bioengineered serpin highly selective for furin: Application as an antipathogenic agent. Proc. Natl. Acad. Sci. USA 1998, 95, 7293-7298. [CrossRef]

102. Khatib, A.M.; Siegfried, G.; Prat, A.; Luis, J.; Chretien, M.; Metrakos, P.; Seidah, N.G. Inhibition of proprotein convertases is associated with loss of growth and tumorigenicity of HT-29 human colon carcinoma cells: Importance of insulin-like growth factor-1 (IGF-1) receptor processing in IGF-1-mediated functions. J. Biol. Chem. 2001, 276, 30686-30693. [CrossRef] [PubMed]

103. Bassi, D.E.; Lopez De Cicco, R.; Mahloogi, H.; Zucker, S.; Thomas, G.; Klein-Szanto, A.J. Furin inhibition results in absent or decreased invasiveness and tumorigenicity of human cancer cells. Proc. Natl. Acad. Sci. USA 2001, 98, 10326-10331. [CrossRef] [PubMed]

104. Kibler, K.V.; Miyazato, A.; Yedavalli, V.S.; Dayton, A.I.; Jacobs, B.L.; Dapolito, G.; Kim, S.J.; Jeang, K.T. Polyarginine inhibits gp160 processing by furin and suppresses productive human immunodeficiency virus type 1 infection. J. Biol. Chem. 2004, 279, 49055-49063. [CrossRef]

105. Remacle, A.G.; Gawlik, K.; Golubkov, V.S.; Cadwell, G.W.; Liddington, R.C.; Cieplak, P.; Millis, S.Z.; Desjardins, R.; Routhier, S.; Yuan, X.W.; et al. Selective and potent furin inhibitors protect cells from anthrax without significant toxicity. Int. J. Biochem. Cell Biol. 2010, 42, 987-995. [CrossRef]

106. Klenk, H.D.; Rott, R. The molecular biology of influenza virus pathogenicity. Adv. Virus Res. 1988, 34, 247-281. [CrossRef]

107. Volchkov, V.E.; Feldmann, H.; Volchkova, V.A.; Klenk, H.D. Processing of the Ebola virus glycoprotein by the proprotein convertase furin. Proc. Natl. Acad. Sci. USA 1998, 95, 5762-5767. [CrossRef]

108. Rawling, J.; Cano, O.; Garcin, D.; Kolakofsky, D.; Melero, J.A. Recombinant Sendai viruses expressing fusion proteins with two furin cleavage sites mimic the syncytial and receptor-independent infection properties of respiratory syncytial virus. J. Virol. 2011, 85, 2771-2780. [CrossRef] [PubMed] 
109. Johnson, B.A.; Xie, X.; Bailey, A.L.; Kalveram, B.; Lokugamage, K.G.; Muruato, A.; Zou, J.; Zhang, X.; Juelich, T.; Smith, J.K.; et al. Loss of furin cleavage site attenuates SARS-CoV-2 pathogenesis. Nature 2021, 591, 293-299. [CrossRef]

110. Sasaki, M.; Toba, S.; Itakura, Y.; Chambaro, H.M.; Kishimoto, M.; Tabata, K.; Intaruck, K.; Uemura, K.; Sanaki, T.; Sato, A.; et al. SARS-CoV-2 Bearing a Mutation at the S1/S2 Cleavage Site Exhibits Attenuated Virulence and Confers Protective Immunity. mBio 2021, 12, e0141521. [CrossRef] 